\title{
Archeological Site As The Idea Source In The Motif Development Of Batik Sragen
}

\author{
Mulyanto \\ Art Education Department, Faculty of Teacher Training and Education, \\ Sebelas Maret University, Surakarta, Indonesia \\ mulyantosr@yahoo.com
}

\begin{abstract}
Sragen Regency in Central Java Province, Indonesia, has an iconic archaeological site that centered in Sangiran area. This site has not been much explored as the idea source for the creation of motifs in batik craft production; whereas batik is one of the main products of Sragen Regency. This research aims to explore the usable elements of the archeological site that can be applied into the motif of batik. Participatory action research, focus group discussion, and creative development were used as research methods as well as empowering batik craft industry. The research has been conducted at Pilang Village, Sragen Regency, especially in Jalidin batik craftsman industry. The result of the research is the batik motif design that brings the concept of prehistoric elephant and bones. The concept is manifested in the elephant combined with bones motif and it is inserted in a machete (parang) pattern. Furthermore, the designed motif is then applied in short-sleeve shirt pattern and produced with several color variations, either using synthetic color or natural dyes. The designed motif is then generated into a batik sanggit in short-sleeves shirt mode.
\end{abstract}

Keywords: archeology, motif, batik, sanggit

\section{Situs Purbakala Sebagai Sumber Ide Pengembangan Motif Batik Sragen}

Kabupaten Sragen, Propinsi Jawa Tengah memiliki situs kepurbakalaan yang berpusat di daerah Sangiran. Situs kepurbakalaan tersebut belum banyak digali untuk dijadikan sebagai sumber ide bagi penciptaan motif-motif dalam produk kriya batik ataupun kriya tekstil bermotif batik. Padahal kriya batik dan kriya tekstil bermotif batik merupakan salah satu produk unggulan Kabupaten Sragen. Tujuan riset ini adalah untuk mengusulkan motif batik yang baru bertolak dari inspirasi situs purbakala sebagai upaya untuk memberdayakan usaha kerajinan batik di Kabupaten Sragen. Metode yang digunakan untuk mencapai tujuan tersebut yaitu kaji tindak partisipatif, metode diskusi kelompok terfokus, dan pengembangan kreativitas pengrajin. Riset dilakukan di Desa Pilang, Sragen khususnya di usaha kerajinan batik Jalidin. Hasil riset yaitu berupa desain motif batik yang berbentuk binatang gajah dan tulang. Kemudian bentuk gajah dan tulang tersebut disusun dalam pola parang dan dibuat pada pola kemeja lengan pendek. Motif tersebut kemudian diproduksi dengan berbagai variasi warna, baik menggunakan zat warna sintetis maupun zat warna alam. Kain batik motif gajah kemudian dibuat menjadi kemeja lengan pendek yang motif-motifnya sanggit di beberapa bagian sambungan jahitan.

Kata kunci: kepurbakalaan, motif, batik, sanggit

Peer review : 9 - 23 Agust 2018, Accepted : 3 September 2018 


\section{INTRODUCTION}

Sragen is one of the regencies in Central Java Province, Indonesia, that has several excellent local products such as teak wood furniture, Beber shadow puppet, stones crafts, organic rice, emping garut, and batik. Batik is a piece of cloth that is decorated with specific harmonic motifs by using dyeing technique with the batik wax as a material for dyeing (Doellah, 2002). In 2016, there are 577 batik industry in Sragen with a total amount of production are 86.455.000 pieces of batik. By this amount, Sragen contributes significantly to the total amount of batik production in Surakarta area. The number of workers absorbed in the batik craft sector is about 8,544 people; the majority of the workers are housewives, who also take part as farmers or farm laborers (Sragen in number, 2015). The center of batik production in Sragen is located in six villages that are Pilang, Kliwonan, Sidodadi, Gedongan, Jabung, and Plupuh.

The Regional Government of Sragen Regency, especially the Department of Industry Cooperative Organization and also the Micro, Small, and Medium Enterprises (SMEs), had arranged several programs to empowering the batik industry. The creative industry empowerment programs are: (1) developing the leading industries, including batik SMEs; (2) improving the efficiency and effectiveness of batik production; (3) evolving the networks of batik SMEs; (4) developing an appropriate capital scheme of batik SMEs; (5) strengthening the marketing management of batik crafts industry; and (6) improving the income of batik craftmans (Sragen in number, 2015).

Pilang Village is the center of batik craft in Sragen Regency. There are 32 batik entrepreneurs and industry in Pilang, which covers the batik craft industry, batik stamp industry, batik combination, batik textile by pull technique, batik textile by wax print technique, and batik textile by full print technique. Generally, most of the batik industry in Pilang as well as in other villages in Sragen area produces Solo-Yogya classical batik motif with a combination between pull and writing technique. The classic motifs of Solo-Yogya refer to the batik motifs that are produced in the Surakarta Kingdom area, such as the motif of $p a-$ rang-lereng pattern, ceplok, and lung-lungan (Susanto, 1980). Commonly, the motif of Solo-Yogya tends to have a geometric pattern in which the motif is spreading across the cloth sections (Doellah, 2002; Roojen, 2001).

Perceiving from the color dimension, batik industry in Sragen commonly uses a systematic color combination such as dark brown, black, and light brown (laseman color). Meanwhile, perceiving from its function, most of the batik industry in Sragen produces jarit or a long cloth. The motif would be difficult to become sanggit or linked each other, particularly in the front side, right side, and left side of the outfits if it is applied into a man or woman outfits, such as

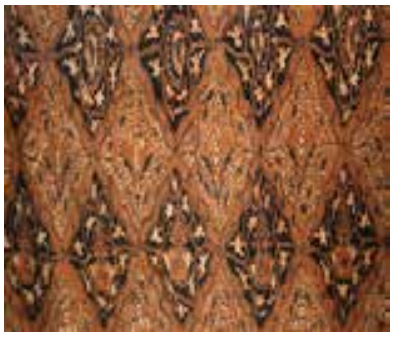

Figure 1. Motif batik ceplok Sidoasih Solo

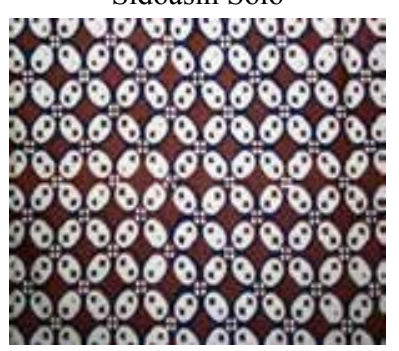

Figure 3. Motif batik Kawung Yogya

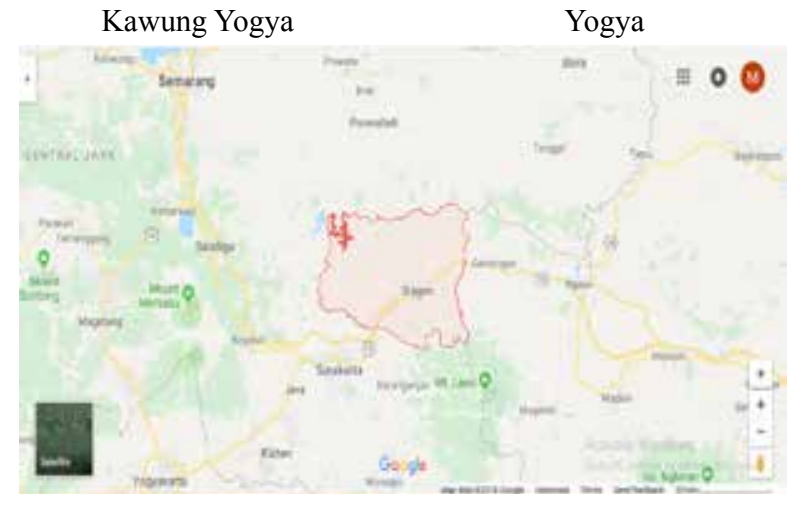

Figure 5. Sragen Regency

a shirt or dress.

Geographically, Sragen located in the border area of Central and East Java. The borderline of Sragen in the eastside is Ngawi Regency, East Java Province; in the west side is Boyolali Regency; in the south side is Karanganyar Regency, and in the north side is Grobogan Regency (see Figure 5). The area of Sragen is about 941,55 kilometers square, which is divided into 20 districts, 8 under-districts, and 200 villages. Physiologically, most of the area of Sragen lies on the flatland with 109 meters above the sea level. Sragen has a tropical climate with the range of daily temperature from 19 Celsius to 31 Celsius. The average of rainfall is below 3.000 millimeters in a year with rainy days below 150 days in a year.

Sragen has an iconic archeological site that centered in Sangiran area. The area of Sangiran is 48 square kilometers that located on the north side of Surakarta city and on the west side of the Bengawan Solo river valley at the foot of Mount Lawu. In 1977, Sangiran was appointed by The Ministry of Education and Culture of Republic of Indonesia as the cultural heritage site, and in 1996, this archeological site was listed in the World Heritage Sites by UNE- 

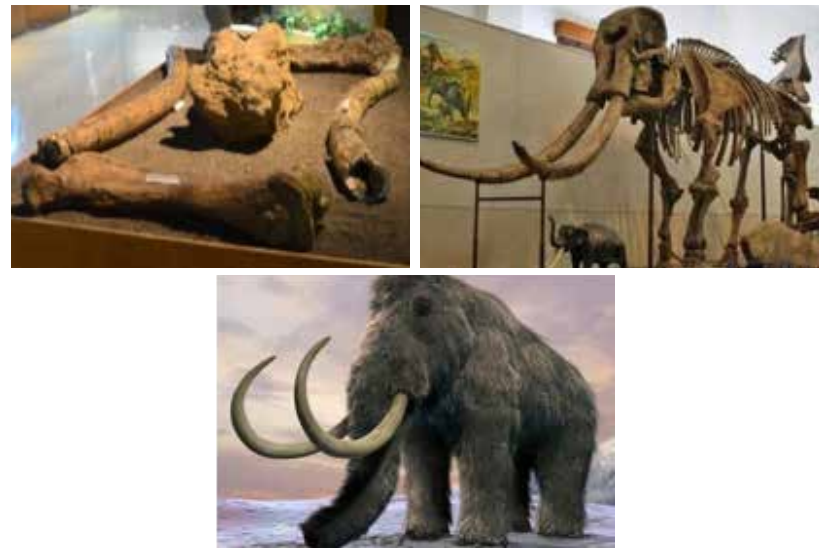

Figure 6. The Collections of Sangiran Museum, Sragen
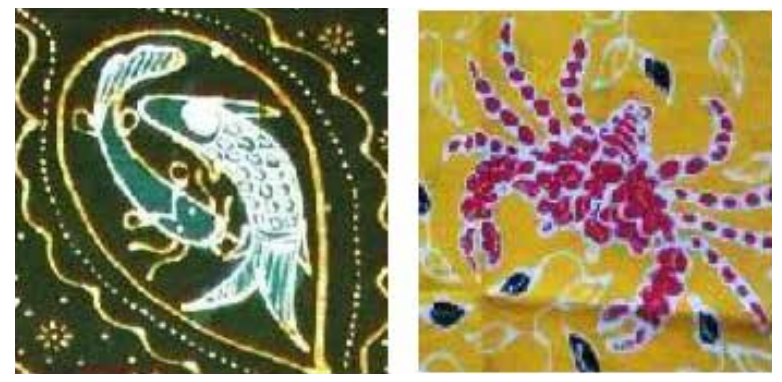

Figure 7. Motif batik of milkfish, catfish and crab

SCO. In 1934, the anthropologist, Gustav Heinrich Ralph von Koenigswald, started his excavation and research in Sangiran. The result of his excavation was the fossil of the first human ancestor, Pithecanthropus Erectus, and about 60 other fossils including the fossil of Meganthropus Palaeojavanicus. The following is a picture of the diorama found at the Sangiran Museum in Sragen Regency (Figure $6)$.

Based on those descriptions, the authors set two problems of research, which are: (1) What relevant archaeological elements in Sangiran that could be used as an idea source of motif development for batik craft industry in Sragen? (2) How the process of motif development from the exploration of archeological elements into the production of motif batik sanggit for men's wear and women wear?

Several types of research have noticed the local excellences as the idea source of motif development. For example, in the cases of Lamongan Regency, East Java, that had developed "milkfish, catfish, and crab" motifs (see figure 7). Those motifs represent the local excellences of Lamongan Regency. Milkfish and catfish are the official symbols of Lamongan Regency, meanwhile, crab is the main local product of the fisheries (Rohmaya and Yulistiana, 2016).

In Jember, the plantation product, such as coffee and cacao, had been explored and developed into batik motifs, such as uwoh coffee motif, godong coffee motif, ceplok cacao motif, cacao king motif, blue cacao motif, and wiji mukti motif (Salma, 2015: 71). In Sleman, the local product, the thorny palm, is explored as the basic idea of the motif de- velopment of batik Sleman (Salma, 2012: 8). Meanwhile, in Cianjur, West Java Province, pelung chicken had been applied as the basic idea to develop the design of bending lamps (Gumulya dan Liony, 2018: 37). Pelung chicken is an endemic animal in Cianjur, which perceive as the pride of the society. This type of chicken is considered by the Cianjur society as the pet and not for mass consumption.

In Garut, West Java Province, the theme of Indonesia Trend Forecasting 2016-2017, that is virology and monstrous with the direction of color composition themed bio pop and refugium become the idea to develop the motif and color composition of woven fabric. The motif and color composition are adjusted with the local wisdom of $u k e l$ that represent the Jaipong Dance motions and the accessories of Golek puppets (Makki, 2017).

The traditional motif of batik also could be developed into the motif of Dobby ATBM woven fabric and bundles that combined simultaneously in one woven fabric. This type of motif is produced in Bandung. The woven fabric with geometric motifs is generated from the differences of attractive yarn color in which the shape of the motif emphasis on the geometric pattern that is combined with the dobby system and weaving bundles (Suantara, 2016).

In the development of batik motif designs, as with other product design plans, there are seven aspects that must be considered. The seven aspects are: (1) The functional aspect that covers the analysis and projection of the problem solver in industrial product towards a feasible and appropriate way thus the product would be more beneficiary to the user. (2) The technical aspect that covers the analysis and calculation of every planning activity towards a consideration of its strength, precision, and utilization of appropriate technology, the material selection, technical specification, the standard of the component, and other aspect that relate to the planning assumption. (3) The ergonomic aspect that covers the analysis and procurement adjustments towards the standard of anthropometry, safety, security, comfortableness, and other aspects that relates to the human physiological aspect. (4) The economic aspect that covers the analysis and calculation of every planning toward the efficiency, effectiveness, and other economic principles so the developed product should be adjusted to the existing economic condition. (5) The ecological aspect that covers a consideration of the utilization of natural resources in responsible ways and consider broadly affected environmental factors. (6) The socio-cultural aspect covers a consideration and adjustment of the planning product with the socio-cultural condition of the society. It means the developed product should be able to harmonize with the cultural dynamic of the society. (7) The visual and esthetic aspect that covers a consideration and efforts to improve the visual quality of the product based on its usage and functions (Prasetyawibowo, 1998). 
According to Clipson (cited by Rizali, 2006), four activities that should be considered in the production process of textile design are problem identification, analysis of production planning, creative process, and production process. Firstly, the problem identification means that in formulating the design should fulfill the need of the consumer. Secondly, the analysis of production planning means that, in one hand, the production process should notice the potency of the consumer such as market share, target share, competition with other producers, attitudes and behavior of potential consumers, consumer purchasing power, and trend of mode. Meanwhile, on the other hand, the product should be aware with their environment that encompasses the social, cultural, economic, and technology environment. Thirdly, the creative process refers to the activities to bring up early ideas of the design. Then, the design should be developed by considering several creative aspects, such as the function of the product, esthetic, product material, technological process, and the trend of mode. Fourthly, the production process means that the product should be tested in a limited range, and after that, the product is permitted to be in mass production.

\section{METHOD}

This research was conducted in 2017 at Pilang Village, Sragen Regency, Central Java, particularly in the Jalidin batik craft industry. Jalidin batik craft industry is the batik craftsman that creatively develops the design of the batik motif. They often participate some the motif design competition and get awarded as the first winner at Sragen Regency level. The Jalidin commonly produces batik by combination technique, for example, the combination between pull and writing technique or wax print and writing techniques. Besides that, the Jalidin also gives service to make a batik design motif, screen batik motif, coloring batik, making a batter batik color, and making wax dough for printing.

The individual and participative approach had been used to develop the batik motif (Mudjiman, 2002). Besides that, the creative development method was used to evolve the creativity of the batik craft industry (Kaufman and Sternberg, 2007). The motif development in this research refers to the process of textile design through four activities that are: (1) problem identification, (2) analysis of product planning, (3) creative process, and (4) the production process.

The developed motif was applied onto the cloth by using wax print technique combined with writing technique. The stages of motif development are as follows (Mulyanto, et. al, 2016a): (1) exploring the site to obtain its esthetic elements as a the basic idea of the early concept, (2) making the motif design in the paper according to the early concept, (3) transferring the concept into batik screen, (4) printing the screen to the cloth by wax technique, (5)

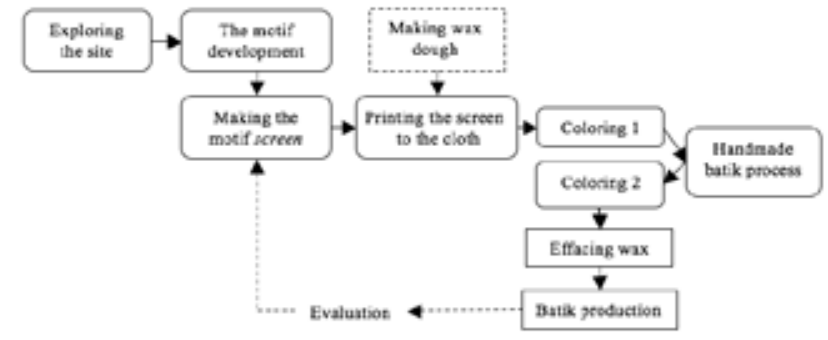

Figure 8. The stages of developing motifs and batik production processes are a combination of print and write techniques drying the wax, (6) first coloring, (7) writing the motif on the certain parts of the cloth (isen-isen motif) (8) second coloring, and (9) effacing the wax. The development stage could be seen in figure 8 below:

\section{RESULT AND DISCUSSION}

As the common process of product development, the activities of motif development, which takes the idea source from the archeological site, should consider the elements and principles of art. The element of visual arts consist of: dot, line, space, form, and color. Dot is the basic element of the artwork. All forms of artwork are derived from a dot. The dot could become the center of attention, if it assembled with other colors. In the motif development based on the archeological site, the dot is applied as an accent inside of isen-isen motif, which has a function to beautify the motif. It signifies that the dot, as the visual entity of batik, becomes the decisive element that beautifies the motif.

The line is the scratches or the limit of the object, space, sphere, color, and texture. The line has elongated dimension and particular direction. The line could be manifested in many natures such as short, long, straight, thin, vertical, horizontal, curve, waves, dash, smooth, bold, italic, and other modified nature. Another impression of the line is to give the motion, idea, symbol, and specific codes to the object of art. In the motif development, the line is used as a medium to reach particular impressions such as creating a strong, simple, and majestic or great impression. In the motif development, the line is applied in form of klowongan motif and small lines for the motif of isen-isen. Several forms of line expression and its impression is adjusted with the chosen colors when it is applied to the cloth.

A space in the art is one of the art elements that is shaped by the connection and intersection of several lines. Space is demarcated by contours and it has a surface and size. The basic spaces in the art are the triangle, quadrilateral, trapezoidal, circle, oval, and many other facets. In the motif development, space could be manifested in the form of a rhombus or space between lines that filled by the motif.

The form could be meant a shape or a plastic form. The shape is the form of a plain object, such as any visible form, such as square, ornamental, irregular and so on. Meanwhile, in the meaning of a plastic form, the form 

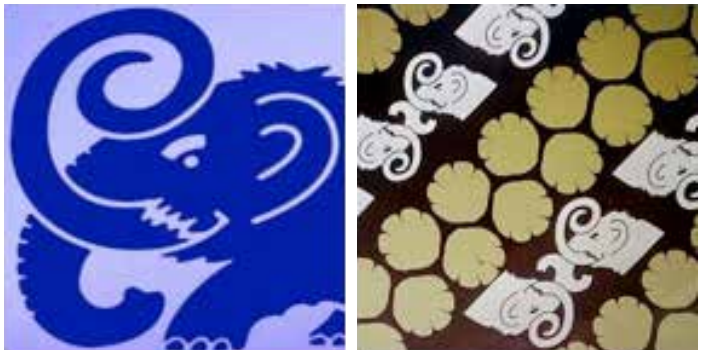

Figure 9. Head and foots of the elephant taken as the batik motif

could mean the visible shape that could be sensed because it has an aesthetic value. In the motif design, the form could be applied to the deformation of the whole forms of bodies, head, trunks, legs, bones, and fossils of elephants.

Color is an impression that emerges from the reflection of light on the eyes. The color usage manifests the specific ornament in the developed motif that is applied by using the synthetic substances or natural dyes. The synthetic substance will produce bright colors, while natural substance will produce soft color. These colors have their own market territory.

The Clipson's theory (cited by Rizali, 2006) was used in this research to develop the motif. The theory of development covers four stages: problem identification, analysis product planning, creative process, and the production process.

Firstly, the problem identification is employed to set the problem of design in which the developed motif should meet with the needs of consumers. At this stage, the researcher should be able to set the product to be made and its motif should be developed in accordance with the consumer need. It means, the producer should be able to make an entrancing outfit, and at the same time, the price of the product must be reachable by the consumer. Based on this consideration, the researcher decided to develop a motif for casual clothes, specifically for batik sanggit in shortsleeves shirt mode. Meanwhile, in order to make the product reachable for the consumer, the production process would be employed by wax print technique.

The archeological elements that could be applied as the basic idea of motif development are the visualization of prehistoric human, prehistoric human life, living enviroment of prehistoric human, prehistoric human farming equipment, prehistoric animals, and other fossils. After the discussion with the batik craftsman, the researcher decided to take visualition of the body, head, legs, trunks, and bones of the elephant (see on figure 9) as the basic idea of motif development.

Secondly, the process of production planning covers an analysis of market potency and market competition, consumer needs and attitude, consumer purchasing power,
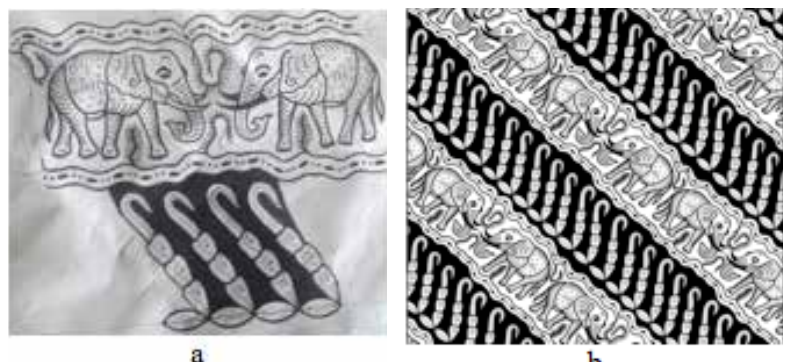

$\mathrm{b}$
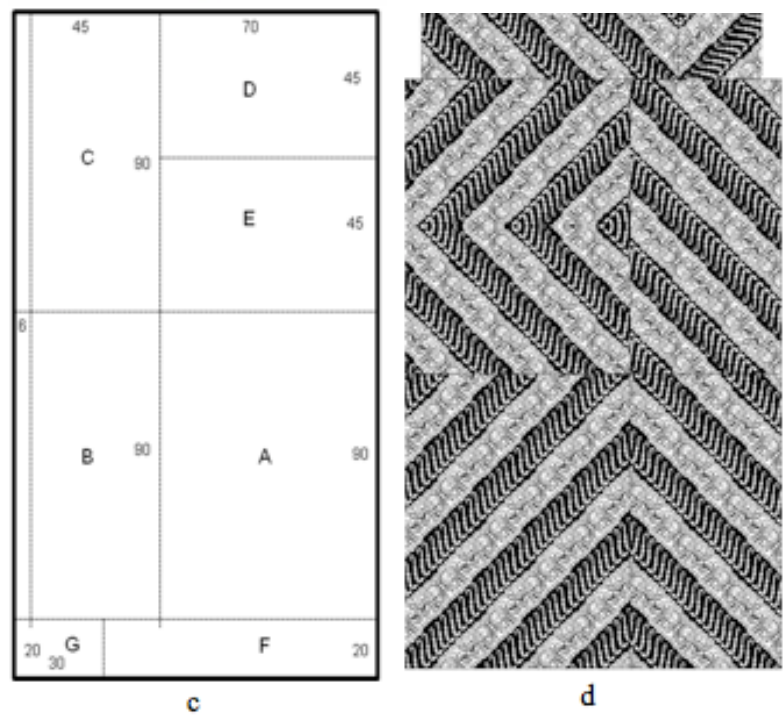

Figure 10a. The elephant and bones motif, 10b. Matches and skews motif, 10c. The short-sleeve shirt pattern $115 \mathrm{~cm} \mathrm{x}$ $200 \mathrm{~cm}, 10 \mathrm{~d}$. The elephant motif is applied on the short-sleeves shirt pattern

and the current fashion mode. Besides that, the product should consider the social, cultural, economic and technology environments. Moreover, the analysis shows that the target market share is the common people who have low purchasing power. The analysis of consumer attitude and behavior shows that the consumer in Sragen area tends to search for the unique batik motif and they rather accept the local product than import product. In addition, the consumer also calculates the price and tends to buy the cheapest one with an average quality product. However, the problem of product prices could be overcome by using wax print technique (see figure 8). For the problem of mode, the consumer had appreciated any fashion mode, both in men's wear or women wears, particularly for the batik with sanggit motif. It because one of the quality criteria for the good outfit in their perception is on its harmonious motif (kesanggitan) on the linked part of the cloth section, such as in the front side, right side, left side, and pocket (see on figure 11).

Thirdly, the creative process employs several activities to bring up an early idea of motif design in which this process considers the creative aspect, such as the functions, esthetic, material, process, and the current fashion mode. In this stage, the researcher notices that the function of the developed product is to make the men or women wear. The materials to make the product are prime cloth or primissima 

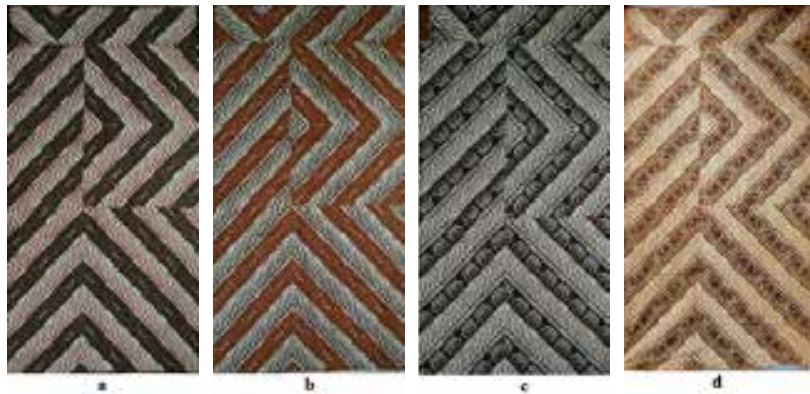

Figure 11. An example of the batik with elephant motif in various colors, 11a, 11b, 11c coloring with synthetic substances, 11d coloring with natural substances

cotton fabrics, synthetic dyes and natural dyes. In order to improve the esthetic aspect of the motif, the elephant motifs combined with bones are inserted in machete (parang) or tilt pattern. The production process uses wax print technique combined with writing technique. Furthermore, the motif is then applied in a short-sleeved shirt pattern (see Figure 10c) in order to make batik sanggit in short-sleeves shirt batik mode in any sizes (M, L, and XL) (Mulyanto, et.al., 2016b). The mode means that the designed motif is applied in the machetes (parang) or skew patterns (see figure 10b).

Fourthly, the production process employs the product trials as well as the process of production. The trials include the screen perfection tests, candle conformity tests with motifs on the fabrics, color compositional harmony tests, and test pattern sizes to make the outfits in size $\mathrm{M}, \mathrm{L}$, or XL. After testing the product, the researcher decided that the product could be produced for mass consumption by using wax print technique combined with writing technique. The steps to produce a batik (see figure 8 ) is started by making the motif design, making screen batik motif, printing the motif on the fabric, drying of wax, first coloring process, making a batik by writing technique, especially for specific part, such as isen-isen, second coloring process, wax removal, and finally the designed motif is produced for mass consumption.

Based on the archeological site, the designed motif uses the motif of two elephant standing face to face each other in combination with the bones (see figure 10a). The motif is arranged at a sloping angle of 45 degrees and it is repeated continuously to make a machete (parang) pattern (see figure 10b). The elephant motif with machete pattern is then applied in the short-sleeve shirt pattern (see figure 10c). The motif is arranged and applied in section A, B, C, D, E, F, and G so they would be matched each other (see figure 10d).

The designed motif, which is already applied in the shortsleeve shirt pattern (figure 10d), is then copied into the screen and processed into cloth by using wax print technique. Furthermore, the cloth was colored by various blend colors. The coloring process uses synthetic substances

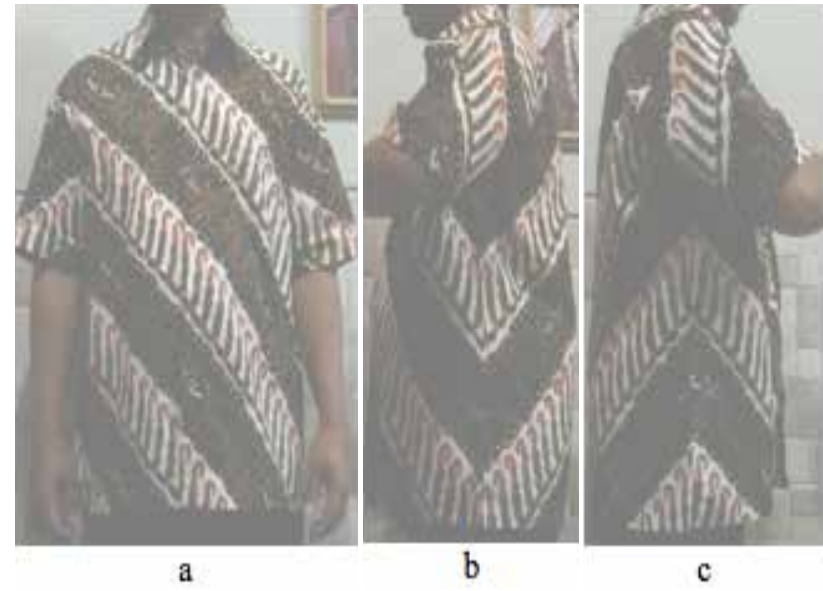

Figure 12. The elephant motif is applied in short-sleeve shirt pattern that sanggit on the front side (12a), left side (12b), and right side (12c).

(figure 11a, 11b, 11c) and natural substances (figure 11d). The colored cloth was then applied into a short-sleeved shirt pattern. The cloth made in the sanggit style in which the linked part of the left and right chests (figure 12a), the left side (figure 12b), and right side (figure 12c) could be harmonized.

\section{CONCLUSION}

Based on the result and discussion, it could be concluded that the batik craftsman, particularly batik designer and dyer, already had an a new idea to develop the batik motif by taking the idea from the archeological site in Sangiran, Sragen Regency. The archeological elements that were used as the basic idea of motif development are the visualization of prehistoric animals such as the figure, head, feet, and bones of the elephant. From those elements, the researcher selected the competent batik craftsman to transform the basic idea from the archeological site into a batik motif that visualized the elephant and bones. The batik craftsman applied the designed motif into a skew or machetes (parang) motif and transformed the motif into a batik in short-sleeve shirt mode. Thus, the product could be generated into a batik outfit in short-sleeve shirt mode for Medium (M), Large (L), or Double Large (XL) in which all the linked part could become sanggit. The designed motif is applied by the combination of technique between wax printing and writing technique. The certain motif is created by writing techniques and colored by various colors. Because it is made by wax print technique, the price of batik could be reduced to be much cheaper than the price of batik made by writing techniques.

\section{REFERENCES}

Doellah, Santoso. (2002). Batik: Pengaruh Zaman dan Lingkungan. Surakarta: PT Batik Danarhadi.

Gumulya, Devanny and Liony Amanda Lee. (2018). Pen- 
carian Identitas Desain Lampu Gentur Cianjur dengan Pendekatan Teori Semiotik. Mudra, Jurnal Seni Budaya, 33(1), 35-47.

Kaufman, J. C. and R. J. Sternberg. Creativity. (2007). Journal of Change, 39(4) (July-August 2007), p.55-57.

Makki, Achmad Ibrahim, Resty Mayseptheny H., Wine Regyandhea Putri. (2017). Pengembangan desain motif kain tenun ikat Garut berdasarkan Indonesia trend forecasting. Arena Tekstil, 32(1), 35-40.

Mudjiman, Haris. (2012). Belajar Mandiri, Surakarta: UNS Press.

Mulyanto and Tjahjo Prabowo. (2016a). Pemberdayaan usaha kerajinan batik Jalidin di Sragen. Laporan Pengabdian [Report of Community Service], Surakarta: LPPM UNS.

Mulyanto, Narsen Afatara, Lili Hartono. (2016b). Desain pola motif tekstil bermotif sebagai upaya pemberdayan industri. Laporan penelitian [Report of Research]. Surakarta: LPPM UNS.

Prasetyowibowo, Bagas. (1998). Desain Produk Industri. Bandung: Yayasan Delapan Sepuluh.

Rizali, Nanang. (2006). Tinjauan Desain Tekstil. Surakarta: LPP UNS.

Rohmaya, Richah and Yulistiana. (2016). Batik Sendang Lamongan. E-Journal. Edisi Yudisium Periode Mei 2016 Pendidikan Tata Busana, Fakultas Teknik, Universitas Negeri Surabaya 5(2), 1-9.

Roojen, Pepin van. (2001). Batik Design. Amsterdam: The Pepin Press BV.

Salma, Irfa'ina Rohana, Anugrah Ariesahad Wibowo, and Yudi Satria. (2015). Kopi dan Kakao dalam kreasi motif batik khas Jember. Jurnal Dinamika Kerajinan dan Batik, $32(2), 63-72$.

Salma, Irfa'ina Rohana and Edi Eskak. (2012). Kajian estetika desain batik khas Sleman "Semarak Salak". Jurnal Dinamika Kerajinan dan Batik, 32(2), 1-8.

Sragen in number. (2015). Bappeda Sragen.

Suantara, Dermawati, Yusniar Siregar, Moekarto Moeliono. (2016). Karakteristik kain ATBM Dobby hasil pengembangan motif batik khas kota Bandung sebagai motif tenun ikat untuk kain kemeja. Arena Tekstil, 31(1), 17-22.

Susanto, Sewan S.K. (1980). Seni Kerajinan Batik Indo- nesia. Jakarta: Balai Penelitian Batik dan Kerajinan, Departemen Industri. 